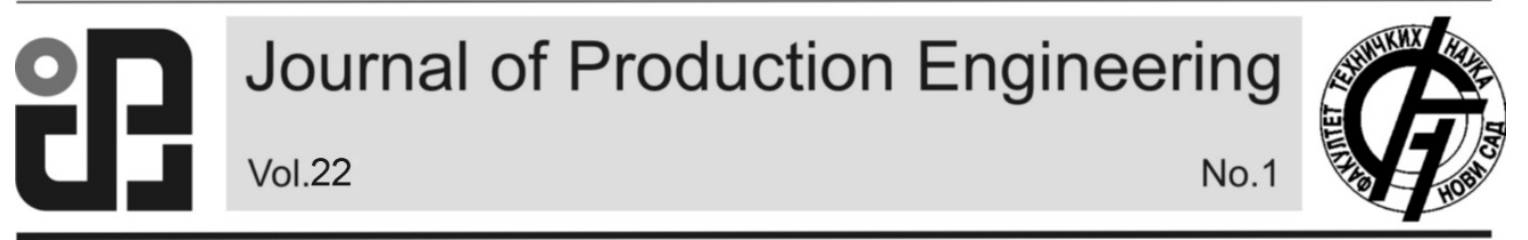

JPE (2019) Vol.22 (1)

Tehami, N.

Original Scientific Paper

\title{
CASTING DEFECTS ANALYSIS IN FOUNDRY AND THEIR REMEDIES: A REVIEW
}

Received: 11 March 2019 / Accepted: 24 May 2019

\begin{abstract}
In this current scenario of globalization, foundries play a key role for manufacturing industries as they are the major source of castings. As a key industry a foundry's performance should be effectively high in terms of production with minimum number of rejections. Castings are the major inputs for most industrial products hence foundry industry is most indispensable. Casting is an integrated process considered as an artwork with experienced professionals for high quality yield, even then in highly controlled environment defects are dominant to take place leading to rejections, contrary to rejections a foundry's key attempt is to satisfy the demands neglecting quality levels. The challenges of casting defects are to be identified and minimized for effective castings. This study provides an intense knowledge of critical casting defects and their root cause analysis. In this paper efforts are made to achieve technically feasible remedies for minimizing several casting defects and improving the quality of castings which will serve as control measures for quality control professionals with zero defect concepts.
\end{abstract}

Key words: casting defects, cause and effect diagram, centrifugal casting, defects analysis.

Analiza defekta liva u livnici i uklanjanje nedostataka: pregled. U trenutnom scenariju globalizacije, livnice igraju ključnu ulogu za proizvodne industrije jer su glavni izvor odlivaka. Kao ključna industrija, performanse livnice bi trebale biti efektivno visoke u smislu proizvodnje uz minimalan broj škarta. Odlivci su glavni pripremak za većinu industrijskih proizvoda pa je livarska industrija najneophodnija. Livenje je integrisani proces koji se smatra umetničkim radom sa iskusnim stručnjacima za postizanje visokog kvaliteta prinosa, čak i onda kada su u visoko kontrolisanim uslovima dominantni nedostaci koji dovode do odbijanja, nasuprot odbijanju ključni pokušaj livnica je da zadovolji zahteve zanemarujući nivoe kvaliteta. Pri nastanku kvalitetnih odlivaka potrebno je indentifikovati $i$ minimizirati greške koje se javljaju pri livenju. Ova studija pruža intenzivno znanje o kritičnim defektima livanja $i$ analizi njihovih uzroka. U ovom radu su napravljeni napori da se postignu tehnički izvodljivi lekovi za minimiziranje nekoliko grešaka u livenju i poboljšanje kvaliteta odlivaka koji će služiti kao kontrolne mere za profesionalne kontrolore kvaliteta sa konceptom nulte greške.

Ključne reči: greške pri lijevanju, dijagram uzroka i posledica, centrifugalno lijevanje, analiza defekata.

\section{INTRODUCTION}

Defects formation in castings is one of the most vexed topics of foundry industries. Foundry industries mostly rely on different process parameters to control such defects ensuring high efficacy of casting with an optimum yield hence controlling of such parameters becomes necessary by sound knowledge of possible causes, for this the probable defects should be analyzed and their root causes have to be studied. This paper brings out the study of castings having prominent defects. The work was carried out based on production trials. An attempt has been made to analyze the critical defects and possible remedial measures are suggested for cast masters to have a sound knowledge about such defects with an aim to minimize rejections rates. The data was collected to take decisive action for quality improvement with reduced rejection in castings [1].

\section{METHODOLOGY}

Cause and Effect diagram is a powerful tool that aids in determining the control factors on quality output.

\section{CASTING DEFECTS}

The major casting defects are classified as follows;

\subsection{Blowhole}

Blowhole is a type of casting defect mostly prevalent in castings, further divided into pin holes, endogenous and exogenous blowholes. Entrapment of air resulting due to pouring of liquid metal takes the form of rounded contours or spherical cavities. Surface blows or inter granular cavities appear in cope of the mould. Pinholes result when the hydrogen present in liquid metal evolves due to less solubility during solidification resulting in triangular appearances, prevalent mostly in thinner castings which are revealed after machining [2].

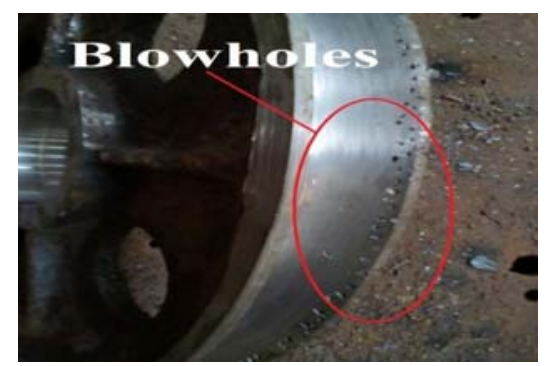

Fig. 1. Blowhole

\subsubsection{Causes}

-Excessive moisture contents in moulding sand.

- Rusted chills and inserts. 
-Very hard ramming.

- Mould not adequately vented.

- Super fine grain size sand.

- Low permeability of casting sand.

-Use of undried coatings.

- Improper mixing of sand.

\subsubsection{Remedial Measures}

- Moisture content should in proper proportions.

- Chills and inserts should be free from rust.

- Ramming should be uniform.

- Mould should be vented properly.

- Grain size of sand should be proper.

- Permeability of sand should be proper.

- Use water based zircon coatings.

- Proper mixing of sand.

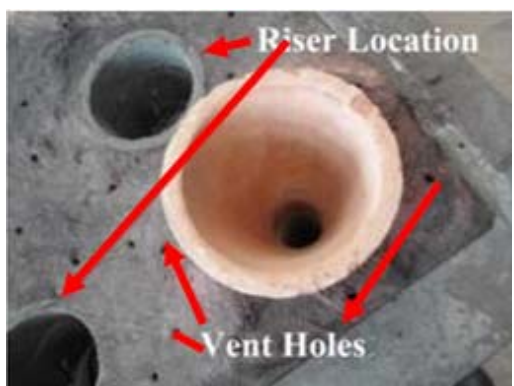

Fig. 2. Vent Holes and Riser Placing

\subsection{Shrinkage}

Shrinkage is a type of casting defect resulting due to formation of shrinkage cavity as such due to lack of design and insufficient feed metal. Shrinkage cavity is a void or depression in the casting caused mainly by uncontrolled and haphazard solidification of the metal. . Shrinkage can be classified into three types as open (macro porosity), closed (internal/blind shrinkage) and axial shrinkage.

Open shrinkage appear on the exterior of casting surface resulting due to volume contraction from liquid to solid state. These are visualized as shallow cavities on casting surface. Closed Shrinkage results due to dense network of dendritic crystals which restricts void feeding of thick sections. Axial shrinkage is a result of long freezing time at the centerline of casting due to high pouring temperature [1].

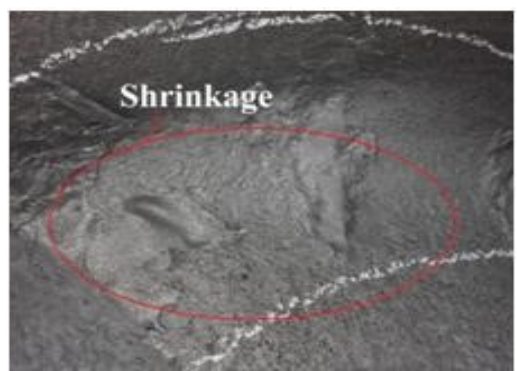

Fig. 3. Shrinkage

\subsubsection{Causes}

- Unevenly dried sand with low compressive strength.

-Mould wall shift due to high metal pressure.

-Chills not placed properly.

-Sudden change in thickness of sections.
-Too many sharp internal corners causing hot-spots isolation.

- Excessive Ferro Silicate use during metal charging.

\subsubsection{Remedial Measures}

- Dry mould using CO2 gas for at least 60 seconds for high rigidity.

- Use of chills at correct position to for directional solidification.

- Feeding of sharp corners to avoid hot spots.

- Riser to be properly located.

- Use of inoculants.

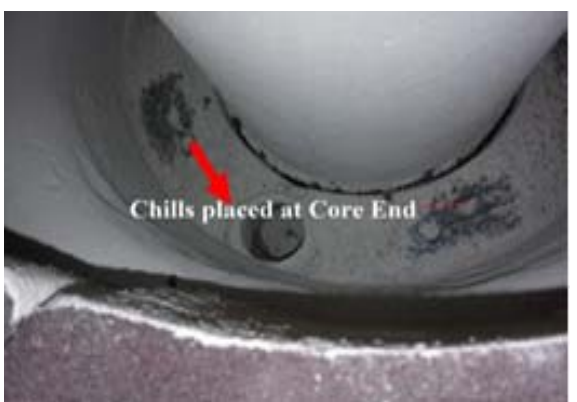

Fig. 4. Chills Placing at Ends

\subsection{Hot Tears}

Hot tears are predominant due to the imbalance in temperature caused during solidification. These appear to be sharp and broken jagged lines at the edges of casting [2].

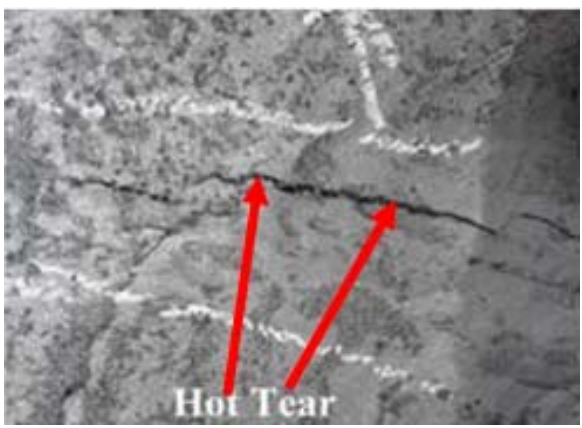

Fig. 5. Hot Tears

\subsubsection{Causes}

- Very hard ramming and excessive mould hardness.

- High dry and hot strength of the sand.

- Very fast solidification of casting.

- Very low pouring temperature.

- Very high sulphur content.

- Hydrogen content too high.

- Low amount of eutectic cells at grain boundary.

- Imperfect riser location.

\subsubsection{Remedial Measures}

- Ramming should be uniform throughout.

- Strength of sand should be appropriate.

- Solidification should be uniform.

- Pouring temperature should be adequate.

- Deoxidize to kill sulphur present.

- Add coal dust to increase eutectic cells during solidification. 


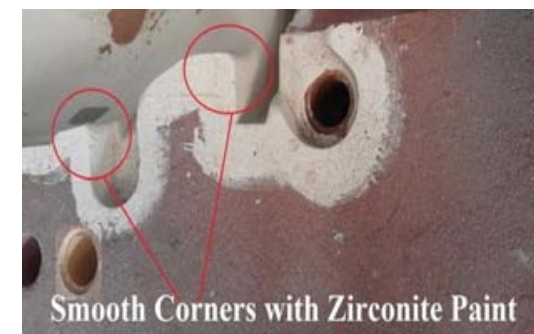

Fig. 6. Smooth Corners with Zirconite Paint

\subsection{Lamination defect}

Lamination is a defect mostly occurring in centrifugally casted pipes especially stainless steel pipes visualized as layer of pipes separated from its adjacent layer appearing as a laminated layer protruding from the pipe [3].

\subsubsection{Causes}

- Use of low quality charge metal and scrap.

- Low rpm or extremely high rpm during pipe solidification. Friction between pipe die and material is low.

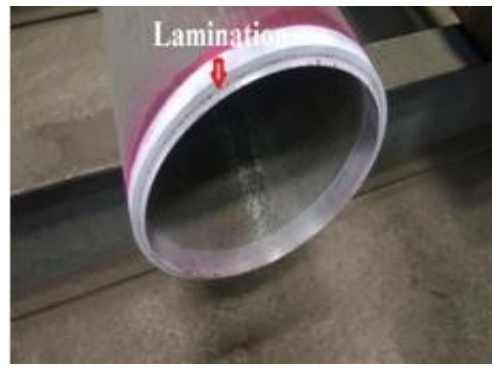

Fig. 7. Lamination

\subsubsection{Remedial Measures}

- Use of best quality metals for charging.

- Pipe should be rotated at optimum speed of $500 \mathrm{rpm}$.

- Locking of pipe die by correct flange size.

- Asbestos sheet for packing should be of good quality and properly aligned in pipe die [4].

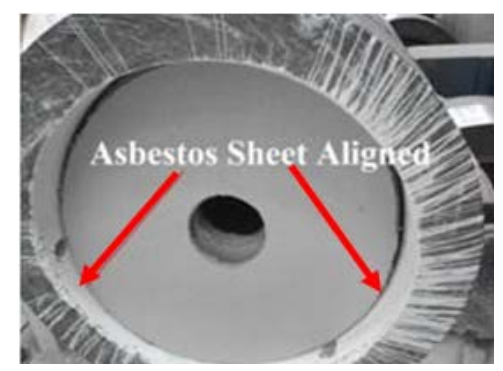

Fig. 8. Asbestos Alignment

\subsection{Mismatch}

Mismatch is another defect which is basically encountered when there is shifting of individual part of a casting with respect to each other [5].

\subsubsection{Causes}

- Due to not proper assembly of lower and upper half of moulding box.

- Worn out of clamping pins.

- Faulty core box.

- Improper location of cores.

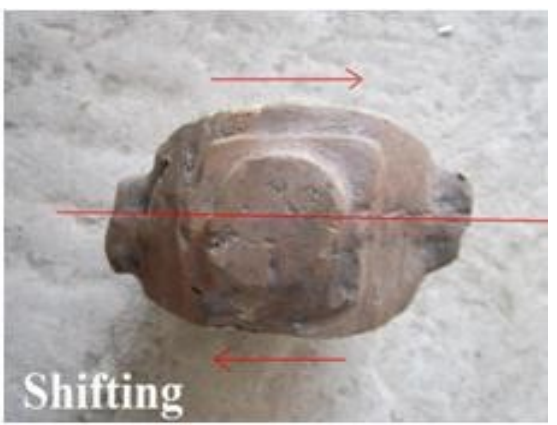

Fig. 9. Mismatch

\subsubsection{Remedial Measures}

- Proper care should be taken while assembling of upper and lower half.

- Proper clamping pins are used.

- Use proper core box.

- Core should be properly located.

- Use proper gating system.

- Heavy weight to be kept on top of casting ensuring no dislocation of cope part.

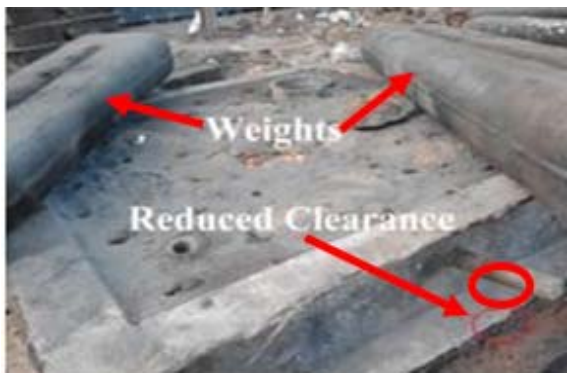

Fig. 10. Heavy Weights on Cope

\subsection{Misrun}

Misrun defect generally caused due to lower fluidity of molten metal. Predominant in castings having large surface area to volume ratio [2].

\subsubsection{Causes}

- Inadequate metal supply.

- Low pouring temperature.

- Metal lacking in fluidity.

- Improper gating system.

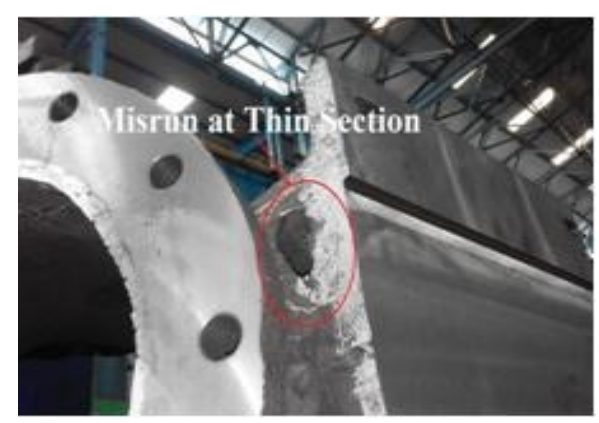

Fig. 11. Misrun

\subsubsection{Remedial Measures}

- Adequate amount of metal supply.

- Pouring temperature should be adequate.

- Metal should have adequate fluidity.

- Use proper gating system.

- Cleaning of mould box before pouring. 


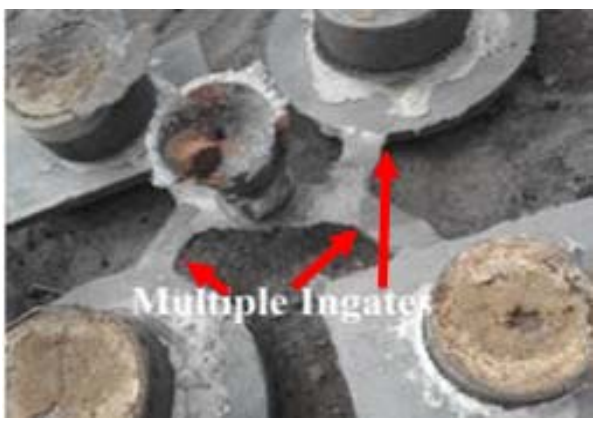

Fig. 12. Multi Gate System

\subsection{Defective Surface}

Streaky lines resulting due to molten metal flow resulting in a pattern of lines which appear as series of small channels is known as defective surface [1].

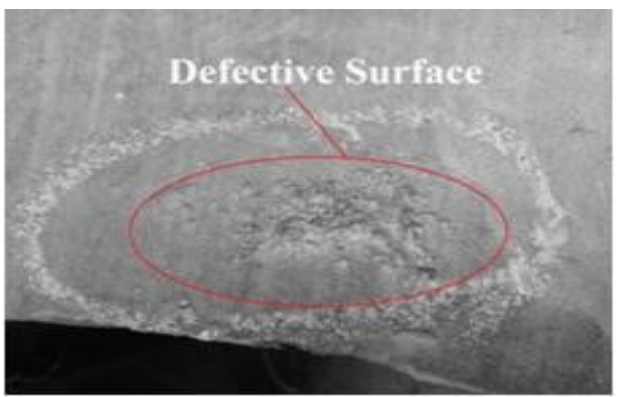

Fig. 13. Defective Surface

\subsubsection{Causes}

- Formation of oxide films.

- Foreign impurities flowing on casting surface.

- Low temperature of mould.

- High slag content.

\subsubsection{Remedial Measures}

- Preheat the mould before pouring.

- Check for slag formation during charge.

- Pouring temperature to be lowered.

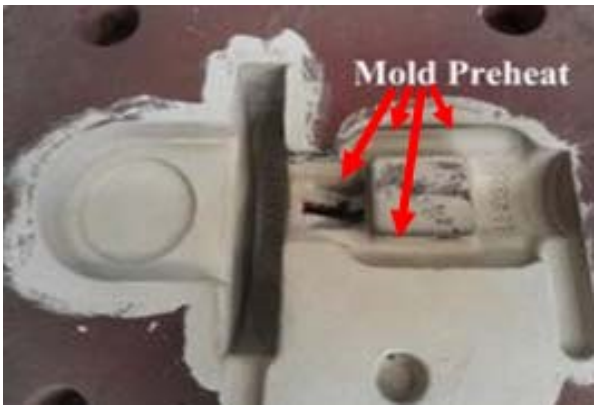

Fig. 14. Mould Preheat At $45^{\circ} \mathrm{C}$

\subsection{Sand Inclusion}

Sand inclusion and slag inclusion are also called as scab or blacking scab. They are inclusion defects. Looks like there are slag inside of metal castings. Irregularly formed sand inclusions, close to the casting surface, combined with metallic protuberances at other points. Sand inclusion is one of the most frequent causes of casting rejection. It is often difficult to diagnose, as these defects generally occur at widely varying positions and are therefore very difficult to attribute to a local cause. Areas of sand are often torn away by the metal stream and then float to the surface of the casting because they cannot be wetted by the molten metal. Sand inclusions frequently appear in association with CO blowholes and slag particles. Sand inclusions can also be trapped under the casting surface in combination with metal oxides and slag's, and only become visible during machining. If a loose section of sand is washed away from one part of the mould, metallic protuberances will occur here and have to be removed [3].

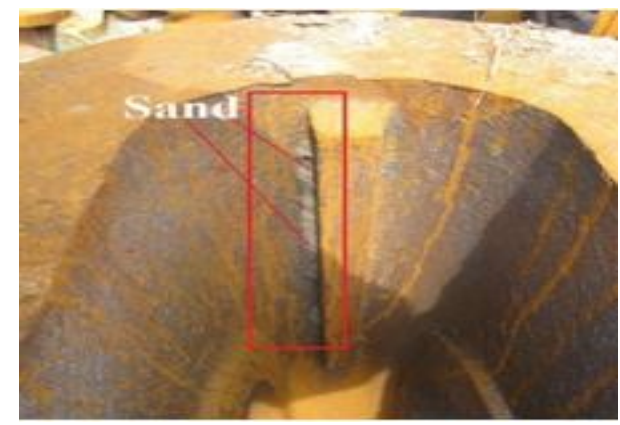

Fig.15. Sand Inclusion

\subsubsection{Causes}

- Tilting of metal stream directly to cores causing erosion.

- Use of unevenly compacted moulds.

- Uneven sand mixing.

- Mould breakage during assembly.

- Improper pouring practices leading to mould disturbances.

\subsubsection{Remedial Measures}

- Use of high bentonite content

- Proper ramming of sand for uniform compaction.

- Frequent cleaning of mould boxes.

- Use of properly of mould boxes.

- Proper mixing ratio of reclaimed sand and binder.

- Proper pouring time.

- Optimum pouring height.

-Increase the strength of cores. Use greater proportion of binder.

- Carefully bloe out mould cavities.

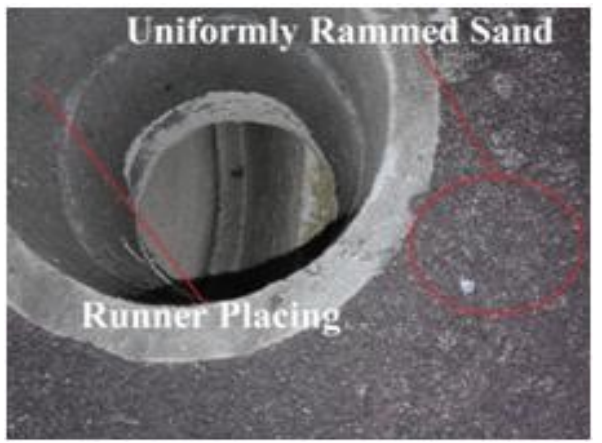

Fig. 16. Sand Ramming and Runner Placing

\subsection{Cold Shunt}

If the molten metal is entering into the mould cavity through more than one gate and the molten metal is meeting physically in mould cavity but not fuse this is referred as cold shunt [2]. 


\subsubsection{Causes}

-Pouring temperature should not so high.

- Inadequate molten metal supply.

- Improper design of gates.

- Restriction in the gates.

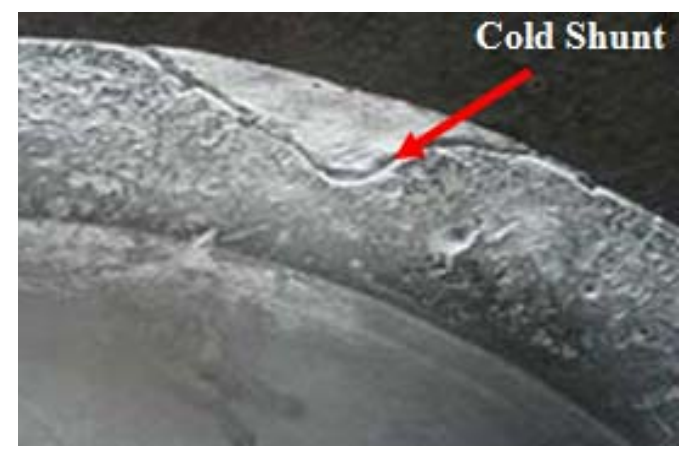

Fig. 17. Cold Shunt

\subsubsection{Remedial Measures}

- Pouring temperature of molten metal should be adequate.

- Supply of molten metal should be uniform.

- Proper design of the gate.

- Gate should be free from any restriction.

\subsection{Flashes}

Flash is an excess material projecting from casting, generally visible as a thin metallic sheet, perpendicular to the casting face. Mostly irregular in thickness occurring along the parting line of mould intersection and acting as hindrance to quality. Hot metal leakage from the platen centre tends the formation of flashes adding extra weight to material $[6,7]$.

\subsubsection{Causes}

- Excessive clearance between top and bottom parts of mould box.

- High pouring pressure.

- Use of mould with poor pattern designs.

- Pattern having cavities at the end.

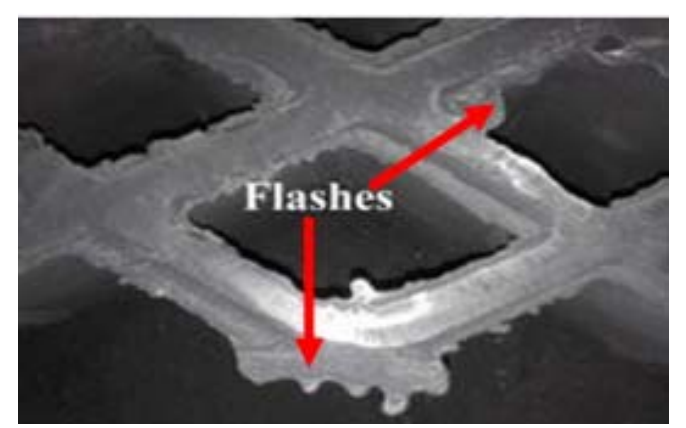

Fig. 18. Flashes

\subsubsection{Remedial Measures}

- Sealing of mould box near parting line.

- Ensure end cavities to be filled to avoid metal leakage.

- Dimensions to be controlled.

- Carefully setting mould assembly.

- Proper core setting.

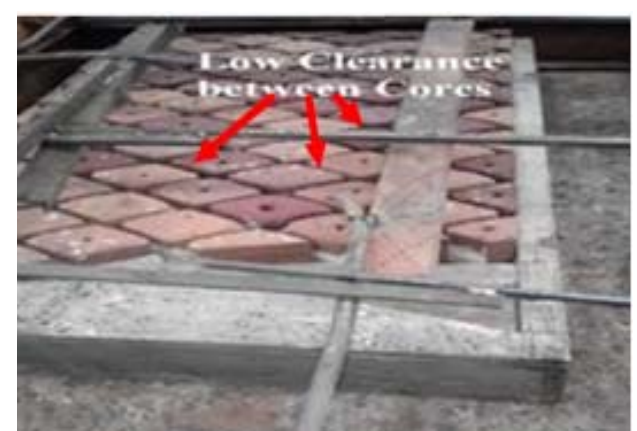

Fig. 19. Core Clearance Setting

\section{CONCLUSION}

A focus on industrial case studies for casting defects is discussed in this paper. By using cause and defect analysis concept the various causes and remedial measures are suggested. This study will be highly useful in reducing casting defects in industries and improving the quality of casting of casting with minimized rejection. Foundry professionals will find it highly useful in increasing the yield of casting.

\section{REFERENCES}

[1] Mr. Avinash Juriani “Casting Defects Analysis in Foundry and Their Remedial Measures with Industrial Case Studies" IOSR Journal of Mechanical and Civil Engineering (IOSR-JMCE) Volume 12, Issue 6 Ver. I in 2015.

[2] Saadat Ali Rizvi, Wajahat Ali, Manufacturing Science-I Katson Book Publishing Company Ltd. New Delhi in 2009.

[3] Achamyeleh A. Kassie and Samuel B. Assfaw "Minimization of Casting Defects" IOSR Journal of Engineering Vol. 3, 2013.

[4] Saadat Ali Rizvi, Wajahat Ali, Optimization of Machining Parameters in Dry Turning of IS 2062 with Taguchi Technique, IJIRSET, Vol. 4, Issue 8,(2015), 7722-7732.

[5] P L Jain, Principles of Foundry Technology Tata McGraw-Hill Publishing Company Limited, New Delhi in 2006.

[6] P.N. Rao, Manufacturing Technology - Foundry, Forming and Welding Tata McGraw-Hill Publishing Company Ltd., New Delhi in 2000.

[7] Kalpakjian, S.,Schmid, S.R., Manufacturing Process and technology, Pearson Upper Saddle River, NJ, USA, (2014).

\section{Acknowledgement}

The author would like to thanks to Dr. Saadat Ali Rizvi Workshop Superintendent of University Polytechnic, Jamia Millia Islamia, New Delhi for helping in writing this review paper and also support me in publishing the paper. Without him it was very difficult to me to publish this review Paper.

Authors: Nashit Tehami, Diploma in Mechanical Engineering student, University Polytechnic, Jamia Millia Islamai, New Delhi. E-mail: ntjmi017@gmail.com 